\title{
Tulane
}

Tulane Economics Working Paper Series

\section{Tax Evasion, Technology, and Inequality}

\author{
James Alm \\ Tulane University \\ jalm@tulane.edu \\ Working Paper 2101 \\ January 2021
}

\begin{abstract}
Ensuring compliance with the tax laws is an enduring challenge for all governments. However, the methods by which governments enforce the tax laws, and by which individuals and firms evade their taxes, change over time, due at least in part to changing technology. In this paper I examine how changing technology, especially changes driven by the transformation of information into digital formats for use by computers, seems likely to affect tax evasion in the years ahead. I argue that many of these changes in technology will improve the ability of governments to decrease tax evasion, mainly by increasing the flow of information to governments. However, I also argue that these changes in technology will open up new avenues by which some individuals and some firms can evade (and avoid) taxes. At this point it is unclear which trend will dominate, so that the effects of technology on the overall level of tax evasion is uncertain. Even so, I believe that the distributional effects of these technological changes are more predictable, given the differential effects of technology on the abilities of individuals of different levels and types of income to evade their taxes. Indeed, I argue that changing technology will make evasion increasingly difficult for most taxpayers, especially those subject to employer withholding and third party information reporting, but that evasion will be increasingly viable for a small number of taxpayers, especially very high income taxpayers. Regardless of the overall impact of technology on the level of tax evasion, I conclude that the effects of technology will likely increase economic inequality.
\end{abstract}

Keywords: Tax evasion; Inequality; Technology; Digitalization

JEL codes: H26; H22; D03 


\title{
Tax evasion, technology, and inequality
}

\author{
James Alm*
}

\begin{abstract}
Ensuring compliance with the tax laws is an enduring challenge for all governments. However, the methods by which governments enforce the tax laws, and by which individuals and firms evade their taxes, change over time, due at least in part to changing technology. In this paper I examine how changing technology, especially changes driven by the transformation of information into digital formats for use by computers, seems likely to affect tax evasion in the years ahead. I argue that many of these changes in technology will improve the ability of governments to decrease tax evasion, mainly by increasing the flow of information to governments. However, I also argue that these changes in technology will open up new avenues by which some individuals and some firms can evade (and avoid) taxes. At this point it is unclear which trend will dominate, so that the effects of technology on the overall level of tax evasion is uncertain. Even so, I believe that the distributional effects of these technological changes are more predictable, given the differential effects of technology on the abilities of individuals of different levels and types of income to evade their taxes. Indeed, I argue that changing technology will make evasion increasingly difficult for most taxpayers, especially those subject to employer withholding and third party information reporting, but that evasion will be increasingly viable for a small number of taxpayers, especially very high income taxpayers. Regardless of the overall impact of technology on the level of tax evasion, I conclude that the effects of technology will likely increase economic inequality.
\end{abstract}

Keywords Tax evasion, inequality, technology, digitalization

JEL Classifications H26, H22, D03

\footnotetext{
* Department of Economics, Tulane University, 6823 St. Charles Avenue, 208 Tilton Hall, New Orleans, LA 70118-5698 (telephone +1 504862 8344; fax +1 504865 5869; email jalm@tulane.edu; ORCID 0000-0003-4008-1637). This paper is based on my keynote address at the $6^{\text {th }}$ Shadow Economy Conference, "Tax Evasion and Economic Inequality", held at the University of Trento in July 2019. I am grateful to conference participants and especially to conference organizers Amadeo Argentiero, Sandro Casal, Marco Faillo, Azzurra Morreale, Luigi Mittone, and Matteo Ploner for many helpful discussions and comments. I also grateful to the editor and to several anonymous referees for many useful and insightful suggestions.
} 


\section{Introduction}

A "good" tax system is one that achieves the goals of equity, efficiency, and adequacy. Tax evasion - when individuals and firms do not pay their legally due tax liabilities in a timely manner - compromises all of these goals. Governments therefore devote many resources in an attempt to combat tax evasion, even while individuals and firms devote many resources to minimizing their tax liabilities. However, both the methods by which governments enforce the tax laws and the methods by which individuals and firms evade their taxes change over time, due to such things as changing tax policies, changing economic forces, changing institutions, changing norms, and changing technology. ${ }^{1}$

In this paper I examine how changing technology seems likely to affect tax evasion in the years ahead, especially technological changes driven by the transformation of information into digital formats for use by computers. I argue that many of these changes in technology will improve the ability of governments to decrease tax evasion, mainly by increasing information available to government, offering government the potential to generate better information, better analysis of this information, and better systems and policies based on this information and its analysis. However, I also argue that these changes in technology will open up new avenues by which some individuals and some firms can evade (and avoid) taxes. At this point it is unclear which trend will dominate, so that the effects of technology on the overall level of tax evasion is uncertain. Even so, I believe that the distributional effects of these technological changes is more predictable, given the differential effects of technology on the abilities of individuals of different levels and types of income to evade their taxes. Indeed, I argue that changing technology will

\footnotetext{
${ }^{1}$ For a wide-ranging discussion of the challenges that tax evasion presents to governance, see the May 2015 Special Issue of Economics of Governance, "The Shadow Economy, Tax Evasion, and Governance".
} 
make evasion increasingly difficult for most taxpayers, especially those subject to employer withholding and third party information reporting, but that evasion will be increasingly viable for a small number of taxpayers, especially very high income taxpayers. Regardless of the overall impact of technology on the level of tax evasion, I conclude that the effects of technology will likely increase economic inequality.

It should be noted at the start that measuring tax evasion is enormously challenging, for obvious reasons. After all, individuals have strong incentives to conceal their tax evasion, as well as other activities that reduce their tax payments like money laundering and tax avoidance, given financial and other penalties that may be imposed on individuals. Even so, research has been increasingly creative in finding data to examine these activities using naturally occurring field data, controlled field experiments, and laboratory experiments. Due to space restrictions, I do not discuss the measurement issues in this paper. ${ }^{2}$

\section{Tax administration, information, and technology}

The basic issue in tax administration has always been getting information on taxpayers and their activities, and for much of history tax administrations did not have full, complete, and timely information. Even during much of the $20^{\text {th }}$ century information has been limited, due to several factors. Many transactions were in cash, so that there was no "paper trail" that could be used to verify the accuracy of any reports. Many types of transactions were not reported via third party information, so again there was no paper trail of transactions. Many types of income were also not subject to source withholding, which also decreased the flow of information to the tax

\footnotetext{
${ }^{2}$ See Alm (2012, 2019), Slemrod (2019), and especially Slemrod and Weber (2012) for recent surveys of the many different approaches to, and difficulties in, measurement. For earlier and still useful discussions of the tax evasion literature, see Cowell (1990) and Andreoni, Erard, and Feinstein (1998).
} 
authorities. Many types of tax shelters were shrouded in secrecy. Many individuals (and firms)

hid income and assets in offshore accounts (e.g., tax havens). Many multinationals were able to shift profits to low-tax jurisdictions via transfer prices that were largely hidden and, even when reported, that could not be independently verified.

Overall, these factors generated several main strategies for tax evasion during much of the $20^{\text {th }}$ century. Individuals (and firms) would fail to report all cash receipts and cash expenses on their tax returns; indeed, many individuals would simply fail to file a tax return. Individuals would use sophisticated tax shelters that were in principle legal forms of tax avoidance but that in practice shaded heavily into illegal forms of tax evasion. Individuals would move income and wealth into hidden offshore accounts, thereby evading any taxes on the hidden income and wealth, and firms would shift profits to lower tax jurisdictions via various strategies, including the manipulation of transfer prices. ${ }^{3}$ The end result was predictable: tax evasion (along with money laundering and tax avoidance) existed, persisted, and flourished in most all countries around the world, largely because tax administrations did not have the information necessary to prevent these practices. ${ }^{4}$

\footnotetext{
${ }^{3}$ More accurately, the ability of firms to shift profits to low tax jurisdictions is a form of legal tax avoidance via "aggressive tax planning" (ATP). An ATP is a tax avoidance transaction that complies with the letter but abuses the spirit of the law. It is typically a sophisticated transaction that includes many steps and uses complex mechanisms. Importantly, it is a transaction that has a limited economic justification, and its true rationale is simply to reduce taxes by exploiting shortcomings, weaknesses, or ambiguities in the tax law via the movement of funds, the construction of fictitious "shell" companies, and the use of financial instruments or entities that are treated differently in different tax jurisdictions. Most commonly, ATPs occur by the use of tax havens, in which profits are shifted from higher to lower tax jurisdictions via such practices as treaty shopping, debt shifting, strategic location of intellectual property, tax deferral, corporate inversions, and, especially, transfer pricing. See Alm (2014) and Alm, Gerbrands, and Kirchler (2020) for a discussion of these types of strategies and of government policies to reduce their use.

4 "Money laundering" is the process of disguising the unlawful source of criminally derived proceeds to make them appear legal, proceeds derived from such sources as illegal arms sales, smuggling, activities of organized crime (e.g., drug trafficking and prostitution), embezzlement, insider trading, bribery, extortion and blackmail, computer fraud schemes, corruption (e.g., "petty" and "grand"), and the like. There are typically three stages involved in money laundering: placement, layering, and integration. See Unger and van der Linde (2015) for a discussion of money laundering strategies and of government policies to combat their use.
} 
However, technological changes have dramatically and fundamentally affected the flow of information to tax administrations. These changes are of course more concentrated in developed countries, but they are also emerging even in developing countries, given especially the efforts of international organizations like the International Monetary Fund and the World Bank, individual country organizations (e.g., U.S. Agency for International Development, Swedish International Development Cooperation Agency, Italian Development Cooperation Programme), and non-profit institutions like the Bill and Melinda Gates Foundation and the Aspen Institute. ${ }^{5}$

Most all of the technological changes start with "digitization", or the transformation of information storage into digital formats (e.g., a series of binary numbers) for use by computers. Computers have opened the doors to a range of methods, all of which affect the flow of information to tax administrations, via:

- Information retrieval and storage

- Information transmission

- Information analysis

Indeed, with the integration of digitization into most all aspects of everyday life, often termed "digitalization", there have been numerous additional technological innovations, creating what Gordon (2016) has referred to as the "Third Industrial Revolution". ${ }^{6}$

Specifically, briefly, and not exhaustively, these technological innovations driven largely by digitalization include the increasing use of or growth in:

- Electronic "cash"

- Electronic commerce

\footnotetext{
${ }^{5}$ The dispersion of technological advances around the is difficult to quantify. As one indicator, an important initiative is the Tax Administration Diagnostic Assessment Tool (TADAT), a collaborative international effort led by various organizations. On a more personal level, I have been involved in many projects in developing countries that have been funded by multiple sources and that have as their overriding goal the improvement of tax administrations via the adoption of modern technology.

${ }^{6}$ See Gupta et al. (2017) for a detailed discussion of digitalization and its effects on government finances.
} 
- Blockchain technology

- Supply chains

- Peer-to-peer (P2P) networks

- "Monopolization"

- "Apps" and the disclosure of personal information

- Biometrics

- "Big data"

- "Deep learning".

Each of these developments emerges in large part from digitization. Although each justifies an in-depth analysis, I only briefly discuss each development. ${ }^{7}$

Electronic "cash". Cash has long been the traditional means of conducting economic transactions, and cash facilitates tax evasion: tracing cash is virtually impossible. However, cash is being supplanted by credit cards, debit cards, and smartphone payment applications, all of which leave an electronic trail. Indeed, some countries have largely moved away from cash (e.g., Sweden), and other countries have even banned the use of high-denomination bills (e.g., India). ${ }^{8}$

Electronic commerce. In part facilitated by electronic "cash", as well as by other technological changes, increasing numbers of transactions occur electronically. In the U.S., electronic commerce has been driven by Amazon, and in China it has been driven by Alibaba. Online commerce is now common in most all developed countries. As estimated by private researchers (e.g., Bruce, Fox, and Luna 2015), public agencies (e.g., the U.S. Department of Commerce), non-profit organizations (e.g., United Nations Conference on Trade and Development), and private firms (e.g., Forrester Research, Inc., Statista, Inc), online commerce has grown steadily in the last several decades, with little sign of any slowing. For example, UNCTAD (2019) recently estimate global sales at \$29 trillion by UNCTAD.

\footnotetext{
${ }^{7}$ For a more detailed discussion of some of these developments, focusing especially on their legal aspects, see Alm et al. (2020).

${ }^{8}$ See Rogoff (2016) for a history of the evolution of currency, along with a detailed analysis of the many ways that large denomination bills facilitate tax evasion.
} 
Blockchain technology. A "blockchain" is a list of records ("blocks") that are linked ("chained") using cryptography, forming an open "distributed ledger" that can record transactions between two parties in a verifiable, permanent, and unalterable way. There are four main characteristics of a blockchain: disintermediation (so lack of centralized information), pseudoanonymity (so lack of information on users), tamper-resistance (so transactions cannot be undone), and autonomy (so automatic execution of transactions). Blockchains are being used in multiple areas, but one of the most prominent is in the development of "crptocurrencies", a digital asset that is typically used as a decentralized medium of exchange. The most widely recognized cryptocurrency is Bitcoin, but in recent years there has been a massive growth in these instruments. At present, it is estimated that there are more than 6000 "altcoins" or cryptocurrencies. ${ }^{9}$

Supply chains. A "supply chain" is a system (or a "chain") of people, activities, information, resources, and organizations that move a product (or a service) from the "supplier" (increasingly multi- or trans-national companies) to the consumer. ${ }^{10}$ In particular, global businesses have considerable flexibility in choosing where to locate their "production", so that they can spread the "production" across multiple geographic locations. For example, a global firm may design the product in multiple jurisdictions; purchase inputs from multiple jurisdictions; produce the product in multiple jurisdictions; assemble the product in multiple jurisdictions; and sell the product in multiple jurisdictions. Further, the global firm has considerable leeway to manipulate "prices" to minimize its tax liabilities via transfer pricing. As a result, the link between "nexus" (or taxable presence) and actual physical presence in a

\footnotetext{
${ }^{9}$ The literature on cryptocurrencies is growing at an enormous pace. See Adrian and Mancini-Griffoli (2019) for a useful overview, along with again Rogoff (2016) for a discussion of both cash and cryptocurrencies.

${ }^{10}$ See Ponte, Gereffi, and Raj-Reichert (2019) and Pagano and Liotine (2020) for recent analyses of the many dimensions of global supply chains.
} 
jurisdiction has become hazy, which makes the measurement, identification, and assignment of tax bases increasingly a challenge for tax administrations.

Peer-to-peer (P2P) networks. Buyers and sellers increasingly engage directly in transactions across a digital platform, by which suppliers and consumers are matched. Each work assignment is akin to performing an individual "gig" (or job) via a short-term relationship with the client, and a gig worker essentially becomes an independent contractor. Some recent examples include ride-hailing (Uber, Lyft), home-sharing (Airbnb, HomeAway), P2P sales (eBay, Etsy), service (Task Rabbit, Postmates). P2P networks also are sometimes called the gig economy, the sharing economy, the access economy, the peer economy, the collaborative economy, the platform economy, the on-demand economy, the matching economy, and the like. These networks are transforming the traditional relationship between suppliers and consumers. ${ }^{11}$ "Monopolization". Many sectors are increasingly dominated by large, nearly monopolistic firms, driven by economies of scale and scope that often arise from technological advances. Specific technology companies like Amazon, Google, Microsoft, Facebook, Apple, Alibaba, and Tencent now dominate their markets, and indeed there is growing concern in governments around the world about the market domination of these companies. There has also been dramatic growth of other related technology companies, including but not limited to Instagram, Twitter, LinkedIn, Snapchat, WeChat, YouTube, Tumblr, Pinterest, SinaWeibo, Reddit, and TikTok. The use of technology has also enabled firms not typically considered "technology firms" to likewise amass dominant market shares in broader sectors like social media, phones, semiconductors, home improvement, appliances, tobacco, glasses, milk, hospitals, health insurance, pharmaceuticals, athletic shoes, airlines, and the like. As a result, an

\footnotetext{
${ }^{11}$ See Kessler (2018) and Belk, Eckhardt, and Bardhi (2019) for analyses of the sharing economy.
} 
increasing share of the labor force in many countries is gravitating toward work in these everlarger business enterprises, all of whom have sophisticated accounting and reporting methods, including employer source-withholding and third party information reporting.

"Apps" and the disclosure of personal information. There are now more mobile devices than there are people - in the entire world. Many of these mobile devices use "apps" of some form, and in many cases the personal information that users reveal when they use these apps is made widely available via social media, including physical location via GPS methods.

Technology companies like those noted earlier are able to gather massive amounts of data on their users. Indeed, it has been estimated that a company like Facebook may collect well over 100,000 data points each year for each of its users, a collection of information that will grow over time and that may be linked to individuals who do not even have a Facebook account. The presence of these massive archives of individual information raises critical privacy issues, given the uses to which these data are typically applied. Importantly, despite company claims, these archives are far from secure, as demonstrated by the many well-publicized hacks and unauthorized sales of these data, including the so-called "Panama Papers" of Mossack Fonseca, Bradley Birkenfeld and UBS, Equifax, and Cambridge Analytica, all of which further raise privacy issues. ${ }^{12}$

Biometrics. "Biometrics" is the measurement of various aspects of human physiology, or distinctive and measurable characteristics used to describe individuals. In many cases these biometric identifiers are fixed (or largely fixed) personal identifiers, like fingerprints, facial

\footnotetext{
${ }^{12}$ For an early but still relevant discussion of privacy issues, see Posner (1981). For a more recent analysis, see Thierer (2013).
} 
features, DNA, and the like. The use of facial recognition technology is a striking illustration of the ways in such biometric-driven technology may be applied. ${ }^{13}$

"Big data". "Big data" refers to data sets that are too large for traditional data processing methods. Examples include financial information, consumer spending patterns, individual health records, social networks, criminal activities, and administrative data. ${ }^{14}$

"Deep learning". "Deep learning" is a catch-all term that includes various digital forms of data analysis. Techniques that can be applied to "big data" include data mining, machine learning, text analytics, cognitive computing, quantum computing, computational research, and artificial intelligence (AI).${ }^{15}$ Indeed, AI can even now anticipate and predict specific modes of tax evasion, based upon individual characteristics, tax return information, and underlying "patterns" in the data.

Summary. In short, digitalization offers the potential - for government but also for private organizations - to generate better information (e.g., more information, more timely information, and more precise information), better analysis of this information (e.g., more powerful and more predictive statistical methods), and better designed systems and policies all based on this information and its analysis. Digitalization also offers the potential for abuse of this information.

Technological changes via digitalization therefore open up new frontiers for government to detect tax evasion, while also presenting to private agents new opportunities for evasion. How

\footnotetext{
${ }^{13}$ See Slemrod (2006) and Logue and Slemrod (2008) for analyses of the ways in which biometric information might be used in the design of tax policies.

${ }^{14}$ See a comprehensive analysis of the ways in which "big data" will transform analytics, see Mayer-Schonberger and Cukier (2013). For a recent discussion of the specific transformational impacts on research in economics, see Currie, Kleven, and Zwiers (2020).

${ }^{15}$ See Gandomi and Haider (2018) for an analysis of "deep learning" applied to "big data".
} 
will these technological changes affect both the ability of government to collect taxes and of private agents to cheat on their taxes?

\section{Technology and its impacts on tax evasion}

\subsection{Toward less tax evasion}

From the standpoint of government and its tax administration, it seems clear that these technological changes vastly improve the ability of government to collect taxes, mainly by increasing the ability of government to track and then to analyze any and all transactions that leave some kind of electronic trail. For example, the decreasing use of cash and the increasing use of digital currencies allow the government to track increasing numbers of transactions because digital currencies create an electronic paper trail that government can use to trace and verify many dimensions of taxpayers' reporting decisions. Further, these innovations increase the ability of government to retrieve information (e.g., the Panama Papers); to transmit this information across jurisdictional borders via linked cross-agency governmental databases, linked international data bases and transparency agreements, as discussed later; and to analyze this information (often with artificial intelligence algorithms). Finally, these innovations allow government to expand greatly the use of tax administration improvements like electronic filing, third party information returns, and presumptive taxes; to track transactions via P2P networks and even perhaps blockchains and supply chains; and to monitor workers in large enterprises subject to third party information and source withholding systems. All of these innovations allow government to reduce the ability of individuals and firms to evade or to avoid their tax obligations. 
To be more specific, there are several specific applications of technology that illustrate the ways in which technology may allow government to generate better information, better analysis of this information, and better systems and policies.

First, consider "deep learning", especially the application of "data mining" to "big data". ${ }^{16}$ As noted earlier, there are some data sets (e.g., "big data") that are too large for traditional data processing methods, and "data mining" involves applying various forms of digital analysis to big data to generate useful information. For example, Amazon has massive amounts of information on individual preferences and purchases of each individual user of its website, and it uses data mining methods to predict the purchase habits of each of these customers. Amazon then uses its predictive model to find other people who fit the same customer profile, which then allows Amazon to make recommendations to these other people based on what these predictions suggest about their behavioral patterns. ${ }^{17}$ In a similar way, the United States Internal Revenue Service (IRS) can apply data mining techniques to its administrative data, in order to determine whether there are specific individual characteristics about which the IRS has detailed information from tax returns and/or third party information reporting (e.g., income amounts and sources, deductions, age, marital status, and the like) that are more likely to be associated with specific tax code violations. The IRS can also make use of other data, such as posts on social media like Facebook, Twitter, Instagram, and so on. In fact, the IRS has always had access to data, and it has always applied state-of-the art statistical methods to the analysis of

\footnotetext{
${ }^{16}$ See Kantardzic (2020) for an encyclopedic analysis of all aspects of data mining.

${ }^{17}$ For example, see Jerry Useem, "How Online Shopping Makes Suckers of Us All”, The Atlantic (May 2017), available online at https:/www.theatlantic.com/magazine/archive/2017/05/how-online-shopping-makes-suckers-ofus-all/521448/?utm_source=atl\&utm_medium=email\&utm_campaign=share.
} 
these data. ${ }^{18}$ However, digitalization has opened up new avenues by which these data can be used and analyzed.

Second, and relatedly, consider artificial intelligence (AI), or the process by which machines attempt to duplicate and even to surpass the cognitive abilities of living creatures. While AI has many dimensions, one of the primary ways that it functions is through the use of algorithms that are performed on a computer, especially algorithms that can self-enhance, becoming smarter as they receive and analyze more data. For example, some recent applications of AI include the development of self-driving cars and of computers that can beat the world's best chess or Jeopardy players. In the context of tax enforcement, recent research has demonstrated that AI can anticipate particular modes of tax evasion, by identifying those tax schemes that taxpayers and their advisers employ to engage in tax evasion, as demonstrated and analyzed by Warner et al. (2015), Hashimzade et al. (2015), Hemberg et al. (2016), and Hashimzade, Myles, and Rablen (2016). AI is especially helpful in seeing detecting patterns of individual use of tax code regulations that can then be used collectively to create a sophisticated - and illegal - tax avoidance scheme.

Third, consider "public-key cryptography". The emergence of the internet has generated concern about user privacy, and, partly in response, computer scientists have developed various modes of cryptography to safeguard personal information, of which "public-key cryptography" is the most prominent. ${ }^{19}$ In principle, public-key cryptography makes the contents of information

\footnotetext{
${ }^{18}$ Note that the IRS has for many years conducted statistical analysis of randomly selected individual tax returns via its "Discriminant Inventory Function" (DIF) scores, in order to target its audits more efficiently (Brown and Mazur, 2003). More recently, the IRS has increasingly relied upon extensive use of information returns, a "big data" initiative analyzed using the "deep learning" computer algorithms of the IRS, in order to ensure that individuals are reporting accurately their incomes. More broadly, the IRS has an in-house data-mining division known as Research, Applied Analytics and Statistics, which develops data-driven compliance initiatives and which coordinates with other government enforcement agencies.

${ }^{19}$ For further discussion and analysis, see the articles in the May 2000 issue of the Stanford Law Review, "Symposium: Cyberspace and Privacy: A New Legal Paradigm?".
} 
exchanged hidden to anyone outside the exchange (Bernstein, 2018). Indeed, this technology underlies the development of blockchains and, through them, cryptocurrencies, both of which are often seen as encouraging tax evasion activities by hiding the names of individuals involved in illegal transactions like money laundering. Even so, there are also potential uses of this technology in IRS enforcement activities. For example, there are many individuals who use fake taxpayer identification numbers to secure fraudulent tax or Social Security refunds. However, if the IRS was to issue a unique and secure "key" to every taxpayer, then each taxpayer can use the individual key to submit tax returns or to claim refunds, all in a secure and fraud-proof manner.

Increasingly, then, certain forms of tax evasion (along with tax avoidance and money laundering) will become much more difficult for individuals and firms. In particular, compliance will almost certainly increase for individuals with income mainly from wages, interest, dividends, and even (realized) capital gains because all of these forms of income will be subject to electronic verification, monitoring, and scrutiny. Put differently, individuals who engage in transactions that leave an electronic trail and who are subject to source withholding and/or third party information reporting will find it virtually impossible to evade or avoid their taxes or to engage in money laundering. These taxpayers represent the vast bulk of taxpayers in all countries around the world.

\subsection{Toward more tax evasion}

Of course, technological innovations are not confined to the government, but are also available to others, at least to varying degrees. The same technologies for information retrieval, transmission, and analysis that are available to government are also accessible to private individuals and firms. This means that the ability of private agents to hide their income and 
assets from government tax administrations is enhanced by the ways in which technology makes easier profit-shifting via transfer pricing, locating intangible assets in low-tax jurisdictions, intragroup debt-shifting, treaty shopping, corporate inversions, and tax deferral. Technology also makes it easier for individuals and firms to utilize global supply chains both for locating income in tax havens and for engaging in tax evasion via money laundering. Blockchains also are seen as making money laundering easier, although it is increasingly believed that the supposed anonymity of blockchains may be somewhat overstated. Finally, the growing use of P2P transactions, many of which involve "independent contractors" and the "informal sector", may in fact make it easier for participants to hide these transactions from the tax authorities, given the relatively small financial size of these taxpayers together with the absence of an electronic trail for many of the P2P transactions.

Again, all of these activities are abetted by the same technologies for information retrieval, transmission, and analysis that are available to government agencies. As a result, it seems likely that certain forms of tax evasion, tax avoidance, and money laundering will actually become easier and more prevalent. Almost certainly, these activities will become easier for multinationals, high-income individuals, and independent contractors.

As before, consider several specific applications of technology that illustrate the ways in which technology may make it easier for individuals and firms to reduce their tax obligations, both legally and illegally: the use of cross-border transactions, of blockchain technology, and of the gig economy.

First, consider the ways in which technology has facilitated cross-border aspects of noncompliance. The electronic transfer of funds, including via the use of cryptocurrencies, makes hiding funds offshore far easier than when the actual physical movement of cash and 
other assets was required. Technology also makes it easier for an individual in one country to manage his or her offshore accounts, even without the need for a physical presence in the offshore location.

A more significant technology-driven threat to a country's tax base likely arises from the use of "aggressive tax practices", all of which allow individuals and especially firms to shift taxable profits from high-tax to low-tax jurisdictions. Many of these strategies employ enormous computer power to implement and track transfer-pricing systems that shift profits. There are also new methods that arise due to the mobility generated by the digital economy. This mobility is reflected in the ability of multinationals to minimize their tax obligations by locating in different jurisdictions such items as business intangibles, users, servers, and even business functions, all with the goal of shifting expenses to high-tax countries and shifting income to low-tax jurisdictions. A multinational corporation has an incentive both to undervalue its transferred intangibles at the time of transfer to an affiliate in a low-tax jurisdiction, and then to allocate large portions of the corporate group's profits to this affiliate based on its legal ownership of the previously undervalued intangible. Similarly, a multinational may contractually allocate functions, assets, and risks to a low-tax affiliate. Most of these transfers rely on the exploitation of technology; that is, there is not a "physical" movement of these functions, but only a "virtual" or an "electronic" movement that determines tax obligations of the multinational.

More generally, technology has made it possible for a nonresident company to interact with customers in a country without any significant physical presence (or "nexus") in that country. This ability to maintain a significant economic presence (e.g., online sales), void of a physical presence (e.g., brick-and-mortar establishment), undermines one of the fundamental touchstones of the international tax system, namely, the idea that physical presence through a 
"permanent establishment" is the critical jurisdictional nexus for allowing source-based taxation.

Indeed, there is emerging if still tentative and somewhat fragile evidence that profitshifting is a growing concern. In several recent papers, Clausing $(2016,2020)$ estimates that between $1 / 4$ and $1 / 3$ of U.S. corporate profits annually escape U.S. taxes due to profit-shifting, leading to revenue losses of well over USD 100 billion per year. Taking a global perspective, Zucman $(2013,2015)$ estimates that more than USD 7.5 trillion is hidden in offshore tax havens (or about 8 percent of global financial wealth) and that over 80 percent of this wealth is never taxed, with a global revenue loss of at least USD 200 billion per year. In more recent estimates, Torslov, Wier, and Zucman (2018) conclude that close to 40 percent of multinational profits are artificially shifted to tax havens each year. All of these estimates have been disputed by Blouin and Robinson (2019), who argue that the existing methodologies are flawed by their inclusion of double-counted profits and/or the misallocation of profits. However, regardless of the specific magnitudes of profit shifting, there is little doubt that its extent is substantial, even if there is still no consensus on its exact magnitude.

Second, consider blockchains. Recall that a blockchain is a decentralized ledger that records ownership and value transfers, with no need for any intermediary. As such, a blockchain provides a way to perform transactions that traditionally required a third party. Indeed, contractual arrangements can be programed into the blockchain and automatically executed once a triggering event occurs (e.g., "smart contracts"). Because the contractual execution is decentralized, neither a party to the contract nor a third party like a government tax administration can prevent execution.

There are clearly benefits to individuals from the legitimate use of this technology. However, this technology also presents challenges to the tax authorities because a blockchain can 
facilitate transfers in ways that are largely hidden from the authorities, due to several of the main features of a blockchain. For example, blockchain technology offers the ability to document value transfers without the need for any intermediary, such as banks, credit card companies, and other financial clearinghouses (e.g., "disintermediation"). The removal of these intermediaries via blockchain technology means that the tax authorities lose any of the information on blockchain transactions that these intermediaries would normally supply to the authorities. This problem of disintermediation is exacerbated by the high level of anonymity (or "pseudoanonymity") that blockchains give their users; that is, blockchain transactions can operate with no need to identify participants, and this anonymity makes it hard for tax authorities to detect the identity of tax cheats who use blockchain especially when transactions are executed automatically (e.g., "autonomy"). Finally, blockchain technology is essentially "tamper resistant", which means that changing any information on any transaction requires that a majority of the network participants must agree to undo the transaction, a near-impossible task. As a result, when tax evasion is involved in a transaction, no financial institution or government can unwind the transaction.

Blockchain is thus a particularly powerful instrument in the hands of tax evaders. Indeed, these blockchain traits have led scholars to note the potential of blockchain technology to be used as an instrument of tax evasion (Marian 2013), and there is at least some anecdotal evidence that the technology is being used as such. Further, the IRS is only now awakening to the challenges presented by blockchains. The IRS has just recently issued updated regulations on the tax consequences of transactions involving cryptocurrencies (https://www.irs.gov/businesses/small-businesses-self-employed/virtual-currencies). While this 
guidance offers some clarity on a few basic issues, it falls well short of answering important questions on the timing, amount, and character of income inclusion in blockchain transactions.

This lack of guidance from the IRS has created opportunities for individuals to use blockchain technology to evade and avoid their tax obligations. These opportunities have flourished, even in the face of recent advances in international tax enforcement, such as the Foreign Account Tax Compliance Act (FATCA)

(https://www.irs.gov/businesses/corporations/foreign-account-tax-compliance-act-fatca), the Financial Action Task Force on Money Laundering (FAFT) (https://www.fatf-gafi.org/), the Organisation for Economic Co-operation and Development (OECD) "Common Reporting Standards" (CRS) framework ((https://www.oecd.org/tax/automatic-exchange/commonreporting-standard/) along with its "Ten Global Principles" (https://www.unglobalcompact.org/what-is-gc/mission/principles), and the G20 and OECD Base Erosion and Profit Shifting (BEPS) framework based in large part on the FATCA model (http://www.oecd.org/tax/beps/). ${ }^{20}$ All of these initiatives are designed to improve international policy coordination, to increase transparency and reporting, and to establish clear sanctions. Even so, both their application and their impact have been uneven. ${ }^{21}$ Third, consider the gig economy. As noted earlier, the term "gig economy" stems from the notion that each work assignment is akin to performing an individual "gig", with gig workers

\footnotetext{
${ }^{20}$ See also OECD $(2000,2013)$.

${ }^{21}$ These information exchanges are intended to provide information to tax administrations in the countries that have agreed to exchange information, thereby reducing the extent of income hidden in offshore accounts. Recent research indicates a mixed impact on offshore deposits of these agreements, sometimes called "Exchange of Information" (EOI) agreements. For example, Beer, Coelho, and Leduc (2019) estimate that the automatic exchange of information reduces foreign-owned deposits in offshore jurisdictions by 25 percent. In contrast, they find that exchange of information only upon request has no consistent impact on foreign-owned deposits. Johannesen (2014) and Johannesen and Zucman (2014) find broadly similar results for different agreements. In recent work, Johannesen et al. (2020) estimate that exchange of information efforts initiated in 2008 by the U.S. Internal Revenue Service caused roughly 50 thousand individuals to disclose offshore accounts with a combined value of about USD 100 billion. Even so, the additional tax revenues that were generated were relatively small, or about USD 1 billion.
} 
expected to maintain only a short-term relationship with their clients. Companies participating in the gig economy operate as online intermediaries that use app- or web-based software platforms to match suppliers and consumers of goods or services. To date, the most mature enterprises of the gig economy are the ride-hailing (e.g., Uber, Lyft) and home-sharing (e.g., Airbnb, HomeAway) platforms. Although the gig economy lacks a universally recognized definition and comprehensive data regarding its operations, there is general agreement on its central features (Kessler 2018; Belk, Eckhardt, and Bardhi 2019): there are many more consumers than suppliers for a given platform, and most workers participate in the gig economy on a part-time basis to earn a secondary income that supplements their primary income.

For purposes of tax compliance, a crucial aspect of the gig economy is that most businesses operating as online intermediaries classify workers as independent contractors instead of employees. This position has been challenged and repeatedly adjudicated. ${ }^{22}$ However, if this position is ultimately upheld, then the predicted growth of the gig economy poses significant compliance issues.

One issue is gig workers' understanding of their tax obligations. A gig worker classified as an independent contractor has tax compliance obligations similar to those of small-business owners or self-employed individuals, both of whom face considerable tax complexity. Because their incomes are not subject to employee tax withholding, they must budget for selfemployment and income taxes themselves and pay quarterly estimated taxes in order to avoid penalty imposition. In addition, when filing their annual tax returns (i.e., Form 1040), gig

\footnotetext{
${ }^{22}$ For example, in April 2018 the California Supreme Court issued a decision in Dynamex Operations West, Inc. V. Superior Court of Los Angeles, a decision that required that all employers classify its workers as employees instead of independent contractors. Then in September 2018 the California State Legislature codified this ruling into law (California Assembly Bill 5 (AB5)). There is now a referendum on the 2020 California ballot that would exempt ridehailing apps from this law. Other states are waiting to see the outcome of this referendum before enacting similar legislation.
} 
workers need to report income earned and expenses incurred on Schedule C (Profit or Loss from Business) and Schedule SE (Self-Employment Tax). Indeed, there is emerging evidence that gig workers lack a basic understanding of how to properly report their taxable income. For example, the National Taxpayer Advocate (NTA) Annual Report to Congress, 2019 lists gig economy noncompliance in its "Most Serious Problem" category. An analysis by the Treasury Inspector General for Tax Administration (TIGTA) lends credence to the NTA's report, finding evidence that between 2012 and 2016 approximately 25 percent of gig workers per year failed to report their incomes in an accurate manner, resulting in billions of dollars of lost tax revenue (TIGTA, 2019). An analysis by Oei and Ring (2017) of online discussion forums (or chatrooms) used by Uber drivers indicates that drivers generally understood tax filing and income reporting requirements, but that their understanding of allowable expenses and deductions was less accurate and more varied, in large part because of the presence of inaccurate and confusing information.

Of more importance, the gig economy has features that encourage noncompliance. There are few if any withholding requirements, there are uncertain information-reporting standards, and there are large incentives for, and few limitations on, overreporting of business expenses and deductions (Thomas 2018). All three features increase the likelihood that gig workers will be noncompliant. For example, consider Uber drivers. Drivers are unlikely to underreport income because the company reports drivers' gross income both to the IRS and to its drivers, including Uber-related fees, reimbursements, miles traveled, and completed trips. However, the company does not report similar information on drivers' expenses. As a result, Uber drivers can recast their personal expenses as business-related expenses, thereby reducing substantially their taxable income. In fact, there is recent research that indicates that drivers are generally honest in their 
reports of gross income but that they also inflate any expenses not subject to third party reporting (Collins et al. 2017; Adhikari et al. 2019; Adhikari, Alm, and Harris 2020).

\subsection{Other considerations}

There are also other considerations that make predictions about the impact of technology on tax evasion quite problematic. Technology may increase the information that taxpayers have about the tax system. However, the effect of this aspect of technology on compliance remains unresolved. For example, field studies often demonstrate that telling individuals that they will be "closely examined" (via a message) generally increases the compliance rate of these individuals; however, the compliance rate of those individuals who infer that they will not be closely examined falls, and the net impact on overall compliance is often negative. Relatedly, laboratory studies indicate that telling individuals about audit results may backfire: if the information that you receive reveals that your "neighbors" are cheating, then you may well tend to cheat yourself. Also, taxpayers often do not know what they should pay in taxes, given a complex tax system, and it has often been suggested that reducing this complexity via, say, better access to technologies like TurboTax will improve compliance. Indeed, laboratory experiments suggest that a more complicated tax system tends to decrease compliance and that better administrative services that make it easier for an individual to pay taxes tends to improve compliance. Even so, these effects are very weak and quite variable. Consequently, there is little firm evidence to support the notion that technological advances giving taxpayers better information about the tax system will improve compliance. See Alm (2019) for a detailed discussion of these issues.

Technology also makes possible new policies that add to the "enforcement", "trust", and "service" paradigms of tax enforcement, policies that have not before been feasible and policies 
that may well affect the practice of tax evasion (Alm and Torgler 2011). Included here are such policies as lifetime-based tax policies, a destination-based cash-flow tax on corporations, dual income taxes, direct capital taxes, global wealth taxes, taxes based on biometric information, taxes with pre-populated tax returns, and taxes that link taxes paid with benefits received. Advances in research (often made possible by technology) may suggest new strategies for collecting taxes, such as changing the wording on tax returns to increase the psychological cost of cheating (e.g., "Did you receive cash or other compensation from employers who did not provide you with a W-2?", "You are required to tell the truth"), changing the wording on tax returns to appeal to "social norms" (e.g., "When taxpayers evade, the entire community suffers", “Please don't be a cheater"), using data-driven "conversational agents" to ask interactive questions adapted to specific taxpayer circumstances in order to reduce tax complexity, or using

online personal taxpayer accounts with third party data retrieval to reduce tax complexity. There are unresolved privacy issues that may make the use of technology harder - or easier. There are also broader economic trends like growing income and wealth equality, declining labor force participation, and expanding use of robots, all of which have implications for tax compliance.

And technology does not of course stand still, and it is impossible to predict the direction of future technological innovations (e.g., "unknown unknowns").

\subsection{Summary}

Which of these trends - those toward less evasion versus those toward more evasion will dominate? It is of course impossible to predict these trends. Even so, I believe that a strong case can be made that the dominant technological trend will be toward the ability of government to access better information, to conduct better analysis of this information, and to design better 
systems and policies, all of which will improve its ability to enforce the tax laws. However, this prediction depends upon two crucial conditions being met.

First, government agencies within each country must be given the resources to access, analyze, and utilize this information, in order to stay ahead of those individuals wishing to cheat on their taxes. Second, government agencies across countries must establish the necessary policy coordination and information exchanges to utilize these new technologies, again in order to stay ahead of those individuals who intend to evade. So my conclusion is that tax evasion will tend to decrease in the future - as long as government tax agency funding is adequate and as long as international policy coordination is achieved. It is certainly possible, even plausible, that both conditions will be met. Even so, one cannot be too sanguine here, if recent history is any guide.

For example, consider funding of the U.S. IRS. According to IRS data, since 2010, IRS funding has fallen by 20 percent, audit rates have fallen well below 1 percent, audit staff has shrunk by 25 percent, revenues from audits have fallen from USD 23 billion to USD 14 billion, and the IRS "Global High Wealth Industry Group" has been effectively eliminated. Clearly, all of these actions reduce the ability of the IRS to utilize new technologies. OECD data suggest that the U.S. experience is not an isolated one.

Similarly, there have been several international initiatives to combat profit shifting, aggressive tax practices, and money laundering, including as noted earlier the U.S. Foreign Account Tax Compliance Act (FATCA), the Financial Action Tax Force on Money Laundering (FAFT), G20/OECD Base Erosion and Profit Shifting (BEPS) Project, and the OECD Common Reporting Standard (CRS). All of these initiatives advance various recommendations designed to improve international policy coordination, to increase transparency and reporting, and to 
establish clear sanctions. ${ }^{23}$ However, to date achieving concrete action has been elusive, largely because countries seem unwilling to cede autonomy on tax affairs to any international organization. Indeed, $12 \mathrm{EU}$ countries recently blocked a law that would have forced multinationals to reveal their profits and their taxes in each of the $28 \mathrm{EU}$ member states. Indeed, there are plausible reasons for the failure of these efforts to improve reporting, based largely on political considerations. For example, the U.S. IRS has a long history of allegations of abuse, in which individuals in power have been accused of using the IRS and its investigative tools to target opposition individuals or groups. ${ }^{24}$ In the face of these allegations, it is common among elected officials of both parties to call for the reform of the IRS, even its abolition, and any politician advocating for increased (or even stable) levels of IRS funding faces significant political opposition. Similarly, there are major political challenges in any efforts to coordinate joint international efforts to share information, to establish common reporting

\footnotetext{
${ }^{23}$ For example, FATCA requires that foreign financial institutions and certain other non-financial foreign entities report on the foreign assets held by their U.S. account holders or be subject to withholding on withholdable payments. FAFT issued 40 recommendations relating to improving national cooperation and coordination, defining money laundering offenses and penalties, defining terrorist financing offenses and sanctions, establishing a framework for improving prevention, establishing a framework for increasing transparence, and improving regulations, among other things. The G20/OECD BEPS project recommends 15 specific actions that are intended to address the tax challenges of the digital economy by such policies as neutralizing the effects of hybrid mismatch arrangements, strengthening controlled foreign company rules, limiting base erosion via interest deductions and other financial payments, preventing treaty abuse, preventing the artificial avoidance of permanent establishment status, assuring that transfer pricing outcomes are in line with value creation, establishing methodologies to collect and analyze data on BEPS, improving dispute resolution mechanisms, and improving transparency. The CRS calls on jurisdictions to obtain information from their financial institutions and to automatically exchange that information with other jurisdictions on an annual basis. More broadly, the "Ten Global Principles" formulated by OECD include actions that: ensure tax offences are criminalized; devise an effective strategy for addressing tax crimes; have adequate investigative powers; have effective powers to freeze, seize, and confiscate assets; put in place an organizational structure with defined responsibilities; provide adequate resources for tax crime investigation; make tax crimes a predicate offence for money laundering; have an effective framework for domestic inter-agency co-operation; ensure that international co-operation mechanisms are available; and protect suspects' rights.

${ }^{24}$ One article of impeachment against then U.S. President Richard M. Nixon in 1974 charged that he had used the IRS against political opponents. Also, widespread publicity of abuses by individual IRS agents led to Senate hearings in 1997 and eventually to passage in 1998 of the IRS Restructuring and Reform Act of 1998, which (among other things) significantly expanded the office of the Taxpayer Advocate. More recently, IRS officials admitted in 2013 that the IRS had subjected conservative political groups to closer scrutiny in their applications for tax-exempt status than liberal political groups.
} 
standards, to distribute enforcement-generated revenues, and the like, given the conflicting interests of the many political actors who are involved, both within and across countries. More broadly, recent research on tax policies in countries has demonstrated that the choice of many structural dimensions of tax systems, including enforcement features, is quite sensitive to political considerations. ${ }^{25}$ It is hardly surprising that calls for increased tax administration funding and/or increased international coordination often go unheeded, given the inherently political dimensions of these calls for action.

\section{Implications for inequality}

These trends have important implications for the distribution of tax burdens across income classes, when the effects of tax evasion are considered in the incidence analysis. Perhaps surprisingly, there has been relatively little work on the distributional effects of tax evasion. Early work by Alm, Bahl, and Murray (1990) for a developing country (Jamaica) indicated that income tax evasion was concentrated in higher income classes, especially through non-filing of tax returns by professionals and small business owners; that is, taxes as a proportion of "true" or "comprehensive" income fell significantly as comprehensive income rose, transforming an income tax that appeared on paper to be a progressive tax into a highly regressive tax. More recent work by Johns and Slemrod (2010) for a developed country (U.S.) also found that the proportion of misreported income relative to "true" income was significantly higher for higher income individuals. In both analyses, tax evasion was found to be proportionately greater as

\footnotetext{
${ }^{25}$ See especially Kenny and Winer (2006), Robinson and Slemrod (2012), Esteller-Moré (2011), Robinson and Slemrod (2011), and Durán-Cabré, Esteller-Moré, and Salvadori (2015). Much of this research builds upon the pioneering political economy work of Hettich and Winer (1999) and Persoon and Tabellini (2000, 2003). I am indebted to an anonymous referee for this suggestion.
} 
income increased. There is now recent and emerging evidence for other countries that suggests a similar result, as discussed in detail later.

Technological changes seem likely to reinforce these patterns. As I have argued earlier, digitalization seems likely to make tax evasion increasingly difficult for those individuals who engage in transactions that leave an electronic trail and who are subject to source withholding and third party information reporting. These individuals will find it virtually impossible to cheat on their taxes, and these individuals represent the vast bulk of all taxpayers, in developing and in developed countries.

In contrast, digitalization seems likely to make tax evasion increasingly easy for multinational companies (via profit-shifting), for high-income individuals (via tax havens and money laundering), and for independent contractors who operate in the P2P economy (via lack of third party reporting, especially on expenses). The actual distributional effects of these likely patterns of tax evasion are not entirely clear. The distributional effects of tax havens and money laundering will accrue largely to higher income individuals. However, the distributional effects for multinationals and for independent contractors are subject to some debate. Ownership of multinationals is heavily concentrated in higher income classes, which suggests that the gains from profit shifting will accrue largely to higher income individuals. Even so, the distributional effects of profit-shifting depend on the incidence of the corporate income tax, about which there is little consensus, especially in a global economy. ${ }^{26}$ The gains from tax evasion by independent contractors operating in the $\mathrm{P} 2 \mathrm{P}$ economy will increase the income of lower income individuals; however, in the aggregate these gains seem likely to be quite small.

\footnotetext{
${ }^{26}$ For a comprehensive review and assessment of the literature on the incidence of the corporate income tax, see Auerbach (2006).
} 
On balance, then, it seems plausible, and even likely, that it will be people mainly at the very top and at the very bottom of the income distribution who will reap the benefits of technology and its effects on tax evasion, with the gains at the top almost certainly far exceeding the gains at the bottom. Indeed, the wealthiest of taxpayers have the political power to reduce their tax burdens, and they use a variety of tools to achieve lower effective tax rates, many of which work through their ability to manipulate the political process to their advantage.

Recent and emerging evidence largely confirms these speculations. Alstadsaeter, Johannesen, and Zucman (2018) use new macroeconomic data published by the Bank for International Settlements to allocate the estimates of Zucman $(2013,2015)$ of global offshore financial wealth (or 8 percent of world household financial wealth) to each country, in order to estimate the amount of household wealth owned by each country in offshore tax havens. They find that the global estimate of offshore wealth hides much heterogeneity in individual country offshore wealth. Their estimates indicate that European countries own about 1/6 of world offshore wealth, and individual countries like Russia Gulf countries, and Latin American countries also own considerable amounts of offshore wealth. Importantly, Alstadsaeter, Johannesen, and Zucman (2018) also find that the ownership of offshore wealth is heavily concentrated at the very top of the wealth distribution, and accounting for offshore wealth dramatically increases the wealth share of the top 0.01 percent, especially in Scandinavian countries, the United Kingdom, Spain, and France.

In related work, Alstadsaeter, Johannesen, and Zucman (2019) use data leaked from HSBC Switzerland (the "Swiss leaks"), the Panama Papers of Mossack Fonseca, and various tax amnesties enacted after the financial crisis of 2008-2009 to examine more directly tax evasion of the very rich. At the time (2007) of the Swiss leaks, HSBC Switzerland was a major player in 
offshore banking, managing assets that represented 5 percent of all foreign wealth in Swiss banks. The leaked data include the complete internal records for 2007 of over 30 thousand HSBC Switzerland clients, many of whom were evading taxes. Alstadsaeter, Johannesen, and Zucman (2019) use these specialized data to link this information to micro-level administrative data for Scandinavian countries (Denmark, Norway, and Sweden), in order to estimate the amount of income that individuals in these countries evaded via offshore banking. They find striking and high levels of tax evasion by the very rich: the 0.01 percent richest households evade nearly 25 percent of their taxes, a level of tax evasion that far exceeds the usual estimates (roughly 5 percent tax of taxes) generated from random tax audits. Although not directly related to distributional issues, the evidence from Johannesen et al. (2020), is also consistent with the concentration of off-shore wealth in the higher - and the very much higher - income classes.

There are of course critical and unresolved concerns about whether these estimates, generated from very specialized data sets and for very specific countries, will apply more broadly. Even so, this evidence is consistent with the conclusion that the distributional effects of tax havens and money laundering will accrue largely to higher income classes. More broadly, the existing evidence is also largely consistent with the conclusion that technological advances will make it easier for the very rich to evade their taxes, even while also making it easier for participants in the $\mathrm{P} 2 \mathrm{P}$ economy to evade their taxes. The challenge for researchers is to find new data and new methods that can quantify these effects well beyond the scope of existing studies.

\section{Conclusions: Tax evasion, technology, inequality}

Which trend - less evasion versus more evasion - will dominate? It is of course impossible to be sure, there are many other trends that will also affect tax evasion in specific 
settings, and each country's experience will necessarily be country-specific. Even so, my first conclusion is optimistic, if qualified: The overall and dominant trend of technology will, I believe, be toward the ability of government to access better information, to conduct better analysis of this information, and to design better systems and policies, all of which will increase its ability to collect taxes. However, my qualifications are important. Government agencies within each country must be given the resources to access, analyze, and utilize this information, and government agencies across countries must establish the necessary policy coordination and information exchanges to utilize these new technologies. Each of these conditions may in fact be realized, but neither is certain, given especially the ways in which political considerations may overwhelm economic and policy considerations.

However, regardless of which trend will dominate overall levels of tax evasion, my second conclusion is more pessimistic, and unqualified: Technology via its effects on the distributional patterns of tax evasion will, I believe, have important effects on economic inequality, almost certainly generating increased inequality.

Specifically, tax evasion will become much more difficult, almost impossible, for individuals with incomes mainly from wages, interest, dividends, and (realized) capital gains because these individuals engage in transactions that leave an electronic trail and they are subject to source withholding and/or third party information reporting. These individuals will find it virtually impossible to cheat on their taxes, and these taxpayers represent the vast bulk of taxpayers in most all countries around the world.

However, these same technologies will make it much more feasible for other types of individuals to evade their taxes. Multinational firms, high-income individuals, and independent contractors especially have both the incentives and the resources to engage in new forms of tax 
evasion. Indeed, the emerging evidence suggests that (with the possible exception of P2P transactions) these new forms of tax evasion are concentrated among high income - in fact, very high income - individuals. The political power of these high income individuals also makes it likely that they will disproportionately benefit from any technological changes.

All of this suggests that technology will make evasion increasingly difficult for most taxpayers, but that technology will also make evasion increasingly viable for high income taxpayers. Regardless of the overall impact of technology on tax evasion, I conclude that the effects of technology will likely increase economic inequality.

However, these are speculations only. One challenge will be to find data that quantify these effects. A more fundamental challenge will be to devise policies that prevent, or at least mitigate, the effects of technology on the incomes of the already very wealthy. Such policies are currently much debated. They likely include such obvious steps as maintaining (and increasing) tax agency funding, improving international policy coordination and information exchange, expanding third party information reporting to include all major margins of behavior, reforming taxation of the $\mathrm{P} 2 \mathrm{P}$ economy, imposing a national or even an international wealth tax, establishing a global minimum corporate income tax, and perhaps even changing the practice of international taxation..$^{27}$ All of these policies are feasible. None are ensured.

\section{References}

Adhikari B, Alm J, Collins B, Sebastiani M, Wilking E (2020) Using a natural experiment in the taxicab industry to analyze the effects of third-party income reporting. Department of Economics Working Paper, New Orleans, LA: Tulane University.

Adhikari B, Alm J, Harris TF (2020) Information reporting and tax compliance. The American Economic Review Papers and Proceedings 110: 162-166.

\footnotetext{
${ }^{27}$ For example, see recent work by Saez and Zucman (2019) on a global wealth tax, Clausing, Saez, and Zucman (2020) on a global minimum corporate income tax, and Avi-Yonah and Clausing (2019), Mason (2020), and Devereux et al. (2020) on comprehensive reform of international taxation.
} 
Adhikari B, Alm J, Harris TF (2020) Small business tax compliance under third-party reporting. Department of Economics Working Paper, New Orleans, LA: Tulane University.

Adrian T, Mancini-Griffoli T (2019) The rise of digital currency. Fintech Note 19/01. Washington, D.C.: International Monetary Fund.

Alm J (2012) Measuring, explaining, and controlling tax evasion: Lessons from theory, experiments, and field studies. International Tax and Public Finance 19 (1): 54-77.

Alm J (2014) Does an uncertain tax system encourage "aggressive tax planning"? Economic Analysis and Policy 44 (1): 30-38.

Alm J (2019) What motivates tax compliance? Journal of Economic Surveys 33 (2): 353-388.

Alm J, Bahl R, Murray MN (1991) Tax base erosion in developing countries. Economic Development and Cultural Change 39 (4): 849-872.

Alm J, Beebe J, Kirsch MS, Marian O, Soled J A (2020) New technologies and the evolution of tax compliance. Virginia Tax Review, forthcoming.

Alm J, Gerbrands P, Kirchler E (2020) Using "response regulation" to reduce tax base erosion. Regulation \& Governance forthcoming.

Alm J, Torgler B (2011) Do ethics matter? Tax compliance and morality. Journal of Business Ethics 101 (4): 635-651.

Andreoni J, Erard B, Feinstein JS (1998) Tax compliance. The Journal of Economic Literature 36 (2): 818-860.

Alstadsæter A, Johannesen N, Zucman G (2019) Tax evasion and inequality. The American Economic Review 109 (6): 2073-2103.

Alstadsæter A, Johannesen N, Zucman G (2018) Who owns the wealth in tax havens? Macro evidence and implications for global inequality. Journal of Public Economics 162: 89-100.

Auerbach AJ (2006) Who bears the corporate tax? A review of what we know. In: Poterba JM (ed.), Tax Policy and the Economy, Volume 20. Cambridge, MA: National Bureau of Economic Research, 1-40.

Avi-Yonah RS, Clausing KA (2019) Toward a $21^{\text {st }}$-century international tax regime. Tax Notes International 26 August 2019: 839-849.

Batchelder LL, Kamin D (2019) Policy options for taxing the rich. In: Kearney MS, Ganz A (eds.), Maintaining the Strength of American Capitalism. Washington, D.C.: The Aspen Institute, 200-234.

Beer S, Coelho M, Leduc S (2019) Hidden treasures: The impact of automatic exchange of information on cross-border tax evasion. IMF Working Paper. Washington, D.C.: International Monetary Fund.

Belk RW, Eckhardt GM, Bardhi F (eds.) (2019) Handbook of the Sharing Economy. Cheltenham, UK and Northampton, MA: Edward Elgar Publishing, Inc.

Bernstein DJ (2018) Protecting communications against forgery. In: J. Buhler J, Stevenhagen P (eds.), Algorithmic Number Theory. New York, NY: Cambridge University Press, 535-549.

Blouin J, Robinson LA (2019) Double counting accounting: How much profit of multinational enterprises is really in tax havens? SSRN Working Paper, available online at http://ssrn.com/abstract=3491451 .

Brown RE, Mazur MJ (2013) The National Research Program: Measuring taxpayer compliance comprehensively. Kansas Law Review 51 (5): 1255-1272.

Bruce DJ, Fox WF, Luna L (2015) E-tailer sales tax nexus and state tax policies. National Tax Journal 68 (3): 735-765. 
Clausing KA (2016) The effect of profit shifting on the corporate tax base in the United States and beyond. National Tax Journal 70 (3): 675-706.

Clausing KA (2020) Profit shifting before and after the Tax Cuts and Jobs Act. SSRN Working Paper, available online at https://ssrn.com/abstract $=3274827$.

Clausing KA, Saez E, Zucman G (2020) Ending corporate tax avoidance and tax competition: A plan to collect the tax deficit of multinationals. SSRN Working Paper, available online at https://ssrn.com/abstract $=3655850$.

Cowell FA (1990) Cheating the Government: The Economics of Evasion. Cambridge, MA: The MIT Press.

Currie J, Kleven H, Zwiers E (2020) Technology and big data are changing economics: Mining text to track methods. NBER Working Paper No. w26715. Cambridge, MA: National Bureau of Economic Research.

Devereux MP, Auerbach AJ, Keen M, Oosterhuis P, Schön W, Vella J (eds.) (2020) Taxing Profit in a Global Economy. New York, NY: Oxford University Press.

Durán-Cabré JM, Esteller-Moré A, Salvadori L (2015) Empirical evidence on horizontal competition in tax enforcement. International Tax and Public Finance 22 (5): 834-860.

Esteller-Moré A (2011) Is the tax administration just a money machine? Empirical evidence on redistributive politics. Economics of Governance 12 (3): 275-299.

Gandomi A, Haider M (2018) Beyond the hype: Big data concepts, methods, and analytics. International Journal of Information Management, 35 (2): 137-144.

Gordon RJ (2016) The Rise and Fall of American Growth: The U.S. Standard of Living since the Civil War. Princeton, NJ: Princeton University Press.

Gupta S, Keen M, Shah A, Verdier G (eds) (2017) Digital Revolutions in Public Finance. Washington, D.C.: International Monetary Fund.

Hashimzade N, Myles GD, Page F, Rablen MD (2016) The use of agent-based modelling to investigate tax compliance. Economics of Governance 16 (2): 143-164.

Hashimzade N, Myles GD, Rablen MD (2016) Predictive analytics and the targeting of audits. Journal of Economic Behavior \& Organization 124: 130-145.

Hemberg, E, Rosen J, Warner G, Wigesinghe G, O'Reilly U-M (2016) Detecting tax evasion: A co-evolutionary approach. Artificial Intelligence and Law 24 (2): 149-182.

Hettich W, Winer SL (1999) Democratic Choice and Taxation: A Theoretical and Empirical Analysis. Cambridge, UK: Cambridge University Press.

Houser KA, Sanders D (2018) The use of big data analytics by the IRS: What tax practitioners need to know. Journal of Taxation 128 (2): 1-15.

Johannesen N (2014) Tax evasion and Swiss bank accounts. Journal of Public Economics 111: 46-62.

Johannesen N, Zucman G (2014) The end of bank secrecy? An evaluation of the G20 tax haven crackdown. American Economic Journal: Economic Policy 6 (1): 65-91.

Johannesen N, Langetieg P, Reck D, Risch M, Slemrod J (2020) Taxing hidden wealth: The consequences of US enforcement initiatives on evasive foreign accounts. American Economic Journal: Economic Policy 12 (3): 312-346.

Johns A, Slemrod J (2010) The incidence of income tax noncompliance. National Tax Journal, 63 (3): 397-418.

Kantardzic, M (2020) Data Mining: Concepts, Models, Methods, and Algorithms (Third Edition). New York, NY: Wiley-IEEE Press. 
Kenny L, Winer S (2006) Tax systems in the world: An empirical investigation into the importance of tax bases, administration costs, scale and political regime. International Tax and Public Finance 13(2-3): 181-215.

Kessler S (2018) Gigged: The End of the Job and the Future of Work. New York, NY: St. Martin's Press.

Logue K, Slemrod J (2008) Genes as tags: The tax implications of widely available genetic information. National Tax Journal 61 (4): 843-863.

Marian, O (2013) Are cryptocurrencies super tax havens? Michigan Law Review 112: 38-48.

Mason R (2020) The transformation of international tax. American Journal of International Law forthcoming.

Mayer-Schonberger V, Cukier K (2013) Big Data: A Revolution That Will Transform How We Live, Work, and Think. New York, NY: Houghton Mifflin.

National Taxpayer Advocate (2019) National Taxpayer Advocate Annual Report to Congress, 2019. Washington, D.C.: Internal Revenue Service, available online at https://taxpayeradvocate.irs.gov/reports/2019-annual-report-to-congress/full-report .

OECD (2000) Towards Global Tax Co-operation: Progress in Identifying and Eliminating Harmful Tax Practices. Paris, France: OECD Publications.

OECD (2013) Addressing Base Erosion and Profit Shifting. Paris, France: OECD Publications.

Oei S-Y, Ring, DM (2017) The tax lives of Uber drivers: Evidence from internet discussion forums. Columbia Journal of Tax Law 8 (2): 56-112.

Pagano AM, Liotine M (2020) Technology in Supply Chain Management and Logistics Current Practice and Future Applications. Amsterdam, The Netherlands: Elsevier B.V.

Persson T, Tabellini G (2000) Political Economics: Explaining Economic Policy. Cambridge, MA: MIT Press.

Persson T, Tabellini G (2003) The Economic Effects of Constitutions: What Do the Data Say? Cambridge, MA: MIT Press.

Ponte S, Gereffi G, Raj-Reichert G (eds.) (2019) Handbook of Global Value Chains. Cheltenham, UK and Northampton, MA: Edward Elgar Publishing, Inc.

Posner RA (1981) The economics of privacy. The American Economic Review Papers and Proceedings 71 (2): 405-409.

Robinson L, Slemrod J (2012) Understanding multidimensional tax systems. International Tax and Public Finance 19 (2): 237-267.

Rogoff KS (2016) The Curse of Cash: How Large Denomination Bills Aid Crime and Tax Evasion and Constrain Monetary Policy. Princeton, NJ: Princeton University Press.

Saez E, Zucman G (2019) The Triumph of Injustice: How the Rich Dodge Taxes and How to Make Them Pay. New York, NY: W.W. Norton \& Company.

Slemrod J (2006) Taxation and "Big Brother": Information, personalization, and privacy in $21^{\text {st }}$ century tax policy. Fiscal Studies 27 (1): 1-15.

Slemrod J (2019) Tax compliance and enforcement. The Journal of Economic Literature 57 (4): 904-954.

Slemrod J, Weber C (2012) Evidence of the invisible: Toward a credibility revolution in the empirical analysis of tax evasion and the informal economy. International Tax and Public Finance 19 (1): 25-53.

Thierer AD (2013) The pursuit of privacy in a world where information control is failing. Harvard Journal of Law \& Public Policy 36 (2): 409-455. 
Thomas KD (2018) Taxing the gig economy. University of Pennsylvania Law Review 166 (6): $1415-1474$.

Torslov T, Wier L, Zucman G (2018) The missing profits of nations. NBER Working Paper No. 24701. Cambridge, MA: National Bureau of Economic Research.

Treasury Inspector General for Tax Administration (TIGTA) (2019) Expansion of the gig economy warrants focus on improving self-employment tax compliance. Washington, D.C.: U.S. Department of the Treasury, Ref. No. 2019-30-016, available online at https://www.treasury.gov/tigta/auditreports/2019reports/201930016fr.pdf.

Unger B, van der Linde D. (eds.) (2015) Research Handbook on Money Laundering. Cheltenham, UK and Northampton, MA: Edward Elgar Publishing, Inc.

Warner G, Wijesiinghe S, Marques U, Badar O, Rosen J, Hemberg E, O'Reilly U-M (2015) Modeling tax evasion with genetic algorithms. Economics of Governance 16 (2): 165-178.

Zucman G (2013) The missing wealth of nations: Are Europe and the U.S. net debtors or net creditors? The Quarterly Journal of Economics 128 (3): 1321-1364.

Zucman G (2015) The Hidden Wealth of Nations. Chicago, IL: University of Chicago Press. 